Rev. Bras. Saúde Prod. Anim., Salvador, v.16, n.1, p.149-160jan./mar., 2015 http://www.rbspa.ufba.br ISSN 15199940 http://dx.doi.org/10.1590/S1519-99402015000100016

\title{
Kinetics of ruminal passage rate of particles of signal grass silage, maize and intercropped $^{1}$
}

Cinética ruminal de passagem de partículas das silagens de capim-braquiaria, de
milho, e do consórcio capim-braquiaria e milho

BELTRÁN, Natalia Andrea Rincón ${ }^{2}$; LEONEL, Fernando de Paula ${ }^{3}$; VILLELA, Severino Delmar Junqueira ${ }^{2}$; TAMY, Wagner Pessanha ${ }^{4}$; CARVALHO, Juliana do Carmo $^{3}$; OLIVEIRA, Margarida Maria Nascimento Figueiredo de ${ }^{2}$; MOREIRA, Leonardo Marmo ${ }^{3}$; MACHADO, Henrique Valentim Nunes ${ }^{3}$; ARAÚJO, Raphael Pavesi $^{3}$

\footnotetext{
${ }^{1}$ Parte da dissertação do mestrado de produção animal apresentada na UFVJM.

${ }^{2}$ Universidade Federal dos Vales do Jequitinhonha e Mucuri, Departamento de Zootecnia, Diamantina, Minas Gerais, Brasil.

${ }^{3}$ Universidade Federal de São João del-Rei, Departamento de Zootecnia, São João del-Rei, Minas Gerais, Brasil.

${ }^{4}$ Universidade Estadual Norte Fluminense, Laboratório de Zootecnia e Nutrição Animal, Campos dos Goytacazes, Rio de Janeiro, Brasil.

*Endereço para correspondência: fernandoleonel@ufsj.edu.br
}

\section{SUMMARY}

The purpose of this study was to evaluate the kinetics of ruminal passage rate of particles from the subsequent associations: corn and signal grass; corn, signal grass and Calopogônio; corn, signal grass and Macrotiloma; and corn, signal grass and Estilosantes. It was used four crossbred holstein-zebu cattle with the rumen tubed in order to determine the the kinetics of ruminal passage rate of particles. The feces were collected at the times zero (immediately after addition of fibers complexed with chromium), $1,2,4,6,8,12,16,20,24,28,32,36,40,44$, $48,56,64,72,80,88,96,120,132,144$ and 192 hours. The profile parameters of passage rate estimative were adjusted according to robust regression procedures. The average time of particles retention in the raft (ATPR1); the average time in the rumen liquid phase (ATRLP2) and the average time of total ruminal retention (ATTRR) were adjusted for the passage kinetics and estimated with the NLIN procedure of SAS. From the observed results, may be suggested that the transference rate $\lambda$ has an inverse behavior to the escape rate $k$, the $\tau$ average values, the average retention time and average particles retention time in the rumen liquid phase (ATRLP2) were not statistically different. The feed characteristics after the raft escape and reach to ATRLP2, were very similar; (ATTRR), related to treatments, were not statistically different $(\mathrm{P}<0,05)$. There were observed small TMRR numerical differences in different foods. The corn and signal grass; corn, signal grass and calopogônio; corn, signal grass and macrotiloma, corn, signal grass and estilosantes silage fibers had similar rates of $\lambda$, $\mathrm{k}$, ATPR1, ATRLP2 and ATTRR. Therefore, the the kinetics of ruminal passage rate of particles is similar. Thus, the choice of the system should be based on other factors, such as viability of the management ease and silage cost.

Keywords: indicators, mordant fiber, raft ruminal, rumen-reticulum, ruminal degradation

\section{RESUMO}

Objetivou-se com este trabalho avaliar a cinética da taxa de passagem ruminal de partículas das silagens oriundas dos consórcios: milho e capim-braquiária; milho, capimbraquiária e calopogônio; milho, capimbraquiária e macrotiloma; e milho, capimbraquiária e estilosantes. Foram usados quatro 
bovinos mestiços holandês-zebu, fistulados no rúmen. As fezes foram coletadas nos tempos zero (imediatamente após a administração da fibra complexada com cromo), 1, 2, 4, 6, 8, 12, $16,20,24,28,32,36,40,44,48,56,64,72,80$, $88,96,120,132,144$ e 192 horas. As estimativas dos parâmetros dos perfis de taxa de passagem foram ajustadas de acordo com procedimentos de regressão robusta. O tempo médio de retenção de partículas no raft (TMR1); o tempo médio de retenção de partículas na fase líquida ruminal $(T M R 2)$ e o tempo médio de retenção ruminal total ( $T M R R$ ) foram ajustados para a cinética de passagem e estimados com o procedimento NLIN do SAS. A partir dos resultados observados, pode-se sugerir que a taxa de transferência $\lambda$ possui comportamento inverso à taxa de escape $k$; os valores médios de $\tau$, os tempos médios de retenção e os tempos médios de retenção de partículas na fase líquida ruminal (TMR2) não diferiram estatisticamente. As características cinéticas dos alimentos, após escaparem do raft e chegarem à fase líquida, foram equivalentes. Os $T M R R$ das fibras das diferentes silagens não diferiram entre si $(P<0,05)$. Observaram-se pequenas diferenças numéricas dos TMRR nos diferentes alimentos. As fibras das silagens em estudo tiveram taxas semelhantes de $\lambda$, k, TMR1,TMR2 e TMRR. Portanto, a cinética da taxa de passagem ruminal de partículas das silagens dos consórcios é semelhante. Assim, a tomada de decisão pelo tipo de consórcio a ser utilizado deve ser baseada em outros fatores, tais como viabilidade do manejo de culturas e custo da silagem.

Palavras-chave: degradação ruminal, fibra mordante, indicadores, raft ruminal, rúmenretículo

\section{INTRODUCTION}

The cattle feeding in grazing is greatly varied in nutrients. It occurs due to changes in forage quality, which suggests a reduction in energy consumption, causing weight loss, poor body condition, and low milk and meat production. The silage use has been an effective solution for low forage production periods, providing good quality forage and being widely used in ruminant feed. Associations between silages, grasses and legumes may have a higher concentration of crude protein in dry matter (DM) and higher DM production per hectare compared to the silage grass exclusive cultivation.

The intercropping system, if well managed, can promote significant increases in productivity, there are several benefits from integrated crop and livestock. However, in most cases, there are views only in the study of quantitative traits, especially the effects on agricultural crop production, such as rice and corn, among others, staying the qualitative, or bromatologic characteristics in the background, such as nutritive and kinetics value of transit and degradation of the forages produced in these systems (LEONEL et al. 2009a; LEONEL et al. 2009b).

Mathematical models are important in various stages of livestock management and optimization (BARIONI et al., 2002). According to Rothember et al. (1989), models are intentional simplifications of reality, since, as biological systems, such as the rumen and the gastrointestinal tract, they are characterized by their organized complexities, being that the model is characterized by the representation of a given system, in a simplified form, with the purpose of extracting relevant features to understand their behavior or to purpose solutions for related problems (CHECCKLAND, 1989). The particles transit kinetics study is evaluated through the use of mathematical models, such as those proposed by Vieira (2008).

In building these models, there were considered the particular characteristics of the food samples as well as anatomical and physiological aspects of animals and processes related to hydration and colonization of substrate 
Rev. Bras. Saúde Prod. Anim., Salvador, v.16, n.1, p.149-160jan./mar., 2015 http://www.rbspa.ufba.br

by ruminal microorganisms. The objective of this work was to evaluate the kinetics of ruminal passage rate of particles of signal grass silage, maize and intercropped, using the mathematical description to its practical application.

\section{MATERIAL AND METHODS}

The silage used to kinetics of ruminal passage rate of particles was derived from material grown in signal grass, corn and legumes intercropping system. These intercrop were established in notillage system at the Risoleta Neves Experimental Farm (FERN), used by agreement with Federal University of Sao Joao del-Rei/EPAMIG.

The intercrops were: corn and signal grass (Brachiaria decumbens) (CSG); corn, signal grass and calopogônio
(Calopogonium mucunoides) (CSGCM); corn, signal grass and macrotiloma (Macrotyloma axillare) (CSGMA); corn, signal grass and estilosantes (Stylosanthes capitata) (CSGSC). Approximately 110 days after planting, when the grains were in dough point, there were carried mechanic harvest and manual silage, been used polyvinyl carbon buckets with capacity for $12 \mathrm{~kg}$ of fresh material, in which there were adapted silicone flanges on the covers to allow the gases escape.

After filling, the buckets were tightly sealed with adhesive tape. At the end of the whole ensiling process (microbial stabilization), there were taken samples to determine the chemical composition, marking fibers with the purpose of evaluating the transit kinetics of particles. The levels of chemical composition (Table 1) were determined according to Silva \& Queiroz (2002).

Table 1. Chemical composition of the silages

\begin{tabular}{|c|c|c|c|c|c|}
\hline Sample & Repeat & $\mathrm{NDF}(\%$ in $\mathrm{DM})$ & $\mathrm{ADF}(\%$ in $\mathrm{DM})$ & $\mathrm{EE}(\%$ in $\mathrm{DM})$ & $\mathrm{CP}(\%$ in $\mathrm{DM})$ \\
\hline CSG & $\mathrm{R} 1$ & 49.6 & 26.2 & 3.96 & 4.00 \\
\hline CSG & $\mathrm{R} 2$ & 48.8 & 21.9 & 2.69 & 4.44 \\
\hline CSG & R3 & 49.4 & 27.3 & 3.59 & 4.69 \\
\hline CSG & $\mathrm{R} 4$ & 54.3 & 29.2 & 3.20 & 4.56 \\
\hline CSGCM & $\mathrm{R} 1$ & 46.5 & 24.0 & 3.18 & 4.56 \\
\hline CSGCM & $\mathrm{R} 2$ & 51.0 & 25.7 & 2.99 & 4.4 \\
\hline CSGCM & $\mathrm{R} 3$ & 48.8 & 25.3 & 3.61 & 4.07 \\
\hline CSGCM & $\mathrm{R} 4$ & 44.3 & 23.3 & 3.74 & 4.83 \\
\hline CSGMA & $\mathrm{R} 1$ & 50.2 & 23.0 & 3.97 & 4.56 \\
\hline CSGMA & $\mathrm{R} 2$ & 49.9 & 24.2 & 4.78 & 4.40 \\
\hline CSGMA & R3 & 44.3 & 22.2 & 5.10 & 4.07 \\
\hline CSGMA & R4 & 50.0 & 24.8 & 4.26 & 4.83 \\
\hline CSGSC & $\mathrm{R} 1$ & 43.0 & 23.4 & 3.13 & 4.74 \\
\hline CSGSC & $\mathrm{R} 2$ & 42.6 & 22.6 & 4.97 & 4.53 \\
\hline CSGSC & $\mathrm{R} 3$ & 45.1 & 23.5 & 3.90 & 4.81 \\
\hline CSGSC & R4 & 46.8 & 23.1 & 4.10 & 4.55 \\
\hline
\end{tabular}

The material was set to boil in a container for one hour in a solution of neutral detergent, in the proportion of $100 \mathrm{~g}$ of dry sample for $100 \mathrm{~mL}$ of 
detergent/liter of water, as described by Udén et al. (1980). After this procedure, the material was filtered in a cotton bag and washed with tap running water, until the clearance of water for the soluble components removal, and, then, placed in an oven at $60 \pm 5^{\circ} \mathrm{C}$ for 72 hours.

Subsequently, we prepared a potassium dichromate solution $\left(\mathrm{K}_{2} \mathrm{Cr}_{2} \mathrm{O}_{7} \cdot 2 \mathrm{H}_{2} \mathrm{O}\right)$ at a ratio of $13 \%$ chromium in relation to the weight of the fiber to be checked. This solution was placed in a glass container, with subsequent immersion of the fiber. The container was covered with aluminum foil and dried in hothouse at $105^{\circ} \mathrm{C}$ for 24 hours. From this procedure, the material was packed in cotton bag and submitted to washing in running water to remove potassium dichromate excess.

Subsequently, the material was immersed in a commercial ascorbic acid solution at the rate of half the fiber weight, and allowed to rest for one hour, until it shows the intense green color. Soon after, the material was again put in a cotton bag and washed repeatedly until the complete clearance of the water and, then, dried in forced air hothouse at $60 \pm 5^{\circ} \mathrm{C}$ for 72 hours.

For the hatching of the marked fibers, there were used four crossbred holsteinzebu cattle with tubed rumen, distributed in Latin square design and conducting four treatments, being four animals and four experimental periods. The crossbred holstein-zebu cattle was maintained in a pasture of signal grass (Brachiaria decumbens), and the cattle was supplemented with $1 \mathrm{~kg} / \mathrm{d}$ of a concentrate containing $290 \mathrm{~g} / \mathrm{kg}$ of soybean meal, $680 \mathrm{~g} / \mathrm{kg}$ of ground corn, and $30 \mathrm{~g} / \mathrm{kg}$ of a commercial mineral salt.

The marked samples were placed in cattle through ruminal tube. The feces were collected at zero (immediately after the addition of fibers complexed with chromium), 1, 2, 4, 6, 8, 12, 16, 20, $24,28,32,36,40,44,48,56,64,72$, $80,88,96,120,132,144$ and 192 hours, to estimate kinetic parameters of particle passage. After harvesting, the samples were dried in forced air at $60 \pm$ $5^{\circ} \mathrm{C}$ for 72 to 96 hours, processed in a Willey mill with $1 \mathrm{~mm}$ mesh sieve and stored for subsequent analyses. The chromium levels in feces samples were analyzed according to the method proposed by Williams et al. (1962). The times of concentration profiles of the feces tracer was set for the compartmental model suggested by Matis et al. (1989):

$C_{t}=6,0 \leq t \leq \tau ;$, o $t>\tau$

$$
C_{t}=C_{0} k\left\{\delta^{N} \exp [-k(t-\tau)]-\exp [-\lambda(t-\tau)] \sum_{h=1}^{N} \delta^{h}[\lambda(t-\tau)]^{N-h} /(N-h) !\right\}+e
$$

Statistical analyses of data using the model above provided estimative of the following parameters, which explain the passage rate dynamics:

$\mathbf{C}=$ concentration of indicator in feces

$\mathbf{N}=$ time dependence order;

$\lambda=$ particles transference from raft

pool to escapable particles pool dispersed in the liquid phase of the rumen;

$\boldsymbol{k}=$ eligible particles escape from the rumen-reticulum for the remainder of the gastrointestinal tract (GIT);

$\tau=$ transit time (time equivalent to the output of the marker from the ruminal 
Rev. Bras. Saúde Prod. Anim., Salvador, v.16, n.1, p.149-160jan./mar., 2015 http://www.rbspa.ufba.br ISSN 15199940

orifice until the first appearance in the feces).

The turnover or average retention time in the rumen-reticulum (ATTRR) was estimated based on biological interpretations, in which both rising and falling phases of the feces tracer excretion pattern may influence the particles retention in the rumenreticulum (VIEIRA et al., 2008). The average particles retention time in the raft (ATPR1) and in the rumen liquid phase (ATRLP2) and the ATTRR were estimated according to the following equations (VIEIRA et al., 2008):

$T M R 1=N / \lambda$,

$T M R 2=1 / k$

$T M R R=N / \lambda+1 / k$.

The model parameters adjusted for the passage kinetics were estimated with the NLIN procedure of SAS (SAS). Both Newton and Marquardt algorithms were used. Initially, the preferred form or algorithm was the Newton one, because of its good performance in terms of convergence. However, when correlations among the parameter estimates were high, the Marquardt algorithm was opted.

There was evaluated the choice of the best version for the time dependence order $(\mathrm{N})$ and, hence, the best model to explain the passage rate, by calculating the Akaike information criterion $\left(\mathrm{AICc}_{\mathrm{h}}\right)$, (AKAIKE, 1974; BURNHAM \& ANDERSON, 2004 ). The $\mathrm{AICc}_{\mathrm{h}}$ was calculated as the sum of squares error $\left(\mathrm{SSE}_{\mathrm{h}}\right)$; number of estimated parameters, including the residual variance $\left(\mathbf{G}_{h}\right)$; and the sample size $\left(\mathrm{n}_{\mathrm{n}}\right)$ for all the different versions of $N, \forall / h=1,2, \ldots, G$ (VIEIRA et al., 2008): The differences of values $\operatorname{AICC}_{h}\left(\Delta_{h}\right)$; the likelihood probability $\left(w_{k}\right)$; and the evidence ratio $\left(E R_{k}\right)$ were also computed using the following equations:

$$
\begin{array}{ll}
A I C c_{h}=n_{h} \ln \left(S S E_{h} / n_{h}\right)+2 \Theta_{h}+2 \Theta_{h}\left(\Theta_{h}+1\right) /\left(n_{h}-\Theta_{h}-1\right) ; \\
\Delta_{h}=A I C c_{h}-\min A I C c_{h i} & \text { reticulum, there were performed some } \\
& \text { variance analyses with a 5\% probability } \\
w_{h}=\exp \left(-\Delta_{h} / 2\right) / \sum_{h=1}^{H} \exp \left(-\Delta_{h} / 2\right) ; & \begin{array}{l}
\text { level compared to the silage. These } \\
\text { analyses were performed using the } \\
E R_{h}=\left(\max w_{h}\right) / w_{h}
\end{array} \quad \text { program STATISTICA (2011). }
\end{array}
$$

The compute of the information criterion permits the hypotheses comparison, and by the results, the selection of one that best predicts the reality according to the data group. The profiles parameters estimative of passage rate were adjusted according to robust regression procedures (BEATON AND TUKEY, 1974), to reduce the effect of outliers, and eliminate subjectivity in the evaluations.

After the estimative of the parameter values from passage dynamics and the average retention time in the rumen-

\section{RESULTS AND DISCUSSION}

Results of the dependence time order can be seen in Table 2. The $\mathrm{N}$ values did not differ among the treatments, except in that used the MBC as food, in which the value was more frequent, $\mathrm{N}=$ 3 . This indicates that the food transit time in the rumen-reticulum, associated with the intrinsic characteristics of the animal, was slower in comparison to others. 
Rev. Bras. Saúde Prod. Anim., Salvador, v.16, n.1, p.149-160jan./mar., 2015 http://www.rbspa.ufba.br ISSN 15199940

Dependence time order $(\mathrm{N})$ is used in dynamical systems theory to describe situations in which the delay mechanisms operate and influence the results of the system output. Vieira et al. (2008) assumed that the order of time dependence decreases with increasing rates of fiber consumption. It averages that the delay mechanisms in the passage rate are probably attenuated with higher rates of food consumption. Quiros et al. (1988) observed that N was greater for large particles when compared to that observed for small particles or liquid. It was assumed that the lower the value, the faster the rate of passage and, therefore, the less can be TMRR.

Table 2. Passage rate and average retention time in different compartments of rumen

\begin{tabular}{lcccccccc}
\hline Animal feed & Animal & $\boldsymbol{N}$ & $\boldsymbol{\lambda}$ & $\boldsymbol{k}$ & $\tau$ & ATPR1 & ATRLP2 & ATTRR \\
\hline CSG & 1 & 1 & 0.271 & 0.028 & 23.8 & 3.69 & 35.71 & 39.4 \\
CSG & 2 & 2 & 0.243 & 0.034 & 20.9 & 8.23 & 29.41 & 37.64 \\
CSG & 3 & 2 & 0.179 & 0.042 & 15.8 & 11.17 & 23.64 & 34.81 \\
CSG & 4 & 1 & 0.195 & 0.037 & 22 & 5.13 & 27.03 & 32.16 \\
CSGCM & 1 & 3 & 0.157 & 0.019 & 16.3 & 19.16 & 52.08 & 71.24 \\
CSGCM & 2 & 1 & 0.225 & 0.042 & 22.4 & 4.44 & 23.81 & 28.25 \\
CSGCM & 3 & 3 & 0.149 & 0.051 & 16.1 & 20.13 & 19.61 & 39.74 \\
CSGCM & 4 & 2 & 0.124 & 0.034 & 16.1 & 16.13 & 29.85 & 45.98 \\
CSGMA & 1 & 1 & 0.099 & 0.021 & 22.2 & 10.12 & 46.73 & 56.85 \\
CSGMA & 2 & 2 & 0.239 & 0.043 & 21.7 & 8.35 & 23.04 & 31.4 \\
CSGMA & 3 & 2 & 0.151 & 0.043 & 18.2 & 13.22 & 23.09 & 36.31 \\
CSGMA & 4 & 1 & 0.083 & 0.052 & 21.2 & 12 & 19.12 & 31.13 \\
CSGSC & 1 & 1 & 0.165 & 0.025 & 29.9 & 6.06 & 40 & 46.06 \\
CSGSC & 2 & 1 & 0.113 & 0.031 & 18.5 & 8.85 & 32.26 & 41.11 \\
CSGSC & 3 & 1 & 0.07 & 0.046 & 18.3 & 14.29 & 21.74 & 36.02 \\
CSGSC & 4 & 2 & 0.157 & 0.06 & 18.4 & 12.74 & 16.67 & 29.41 \\
\hline
\end{tabular}

$\mathbf{N}=$ time dependence order; $\lambda=$ particles transference from raft pool to escapable particles pool dispersed in the liquid phase of the rumen; $\boldsymbol{k}=$ eligible particles escape from the rumen-reticulum for the remainder of the gastrointestinal tract (GIT); $\boldsymbol{\tau}=$ transit time (time equivalent to the output of the marker from the ruminal orifice until the first appearance in the feces). ATPR1 = Average retention time of particles in the raft; ATRLP2 $=$ Average retention time of ruminal particles in the liquid phase; ATTRR $=$ Average retention time in the rumen-reticulum.

Considering the fiber retention time in the rumen-reticulum, the first paradigm, apparently most accepted as true, denotes this mass of ruminal fiber as a homogenous sum. Furthermore, this mass modeling is minimally divided in two compartments: potentially digestible fraction and indigestible fraction of the consumed fiber. This paradigm fails in its predictive power (HUHTANEM et al., 1995; VIEIRA et al., 2000, 2008). However, the model is in use within the different feeding systems (AFRC, 1993,
1997; NRC, 1996, 2001; FOX et al., 2004).

Texas researchers (Ellis \& Matis) proposed an alternative model based on the assumption that fiber retention in agreement with Robert E. Hungate. This model was built based on passage profiles of undigested fibrous material. These profiles are produced by two retention compartments in the rumenreticulum and, subsequently, follow a laminar flow over the remainder of the gastrointestinal tract (GIT) until the first 
appearance of this material in the feces (VIEIRA et al., 2008). This alternative kinetic interpretation would produce more credible predictions about the dynamics of fiber in the rumen. Therefore, this study adopted the paradigm to assess and explain the rates that describe the dynamics of the fiber in the rumen-reticulum.

At trial, the diet fed to animals was corn silage. The parametric values found for the different treatments may have been influenced by the diet furnished to the animals, since the rumen microorganism were adapted to this kind of food.

Average $k$ values were not statistically different $(\mathrm{P}<0.05)$. However, there was a compensation for the $k$ escape rate from the $\lambda$ transference rate for different treatments. Thus, according to the results, it is assumed that the $\lambda$ transference rate has an inverse rate to the $k$ escape rate, as shown in Figures 1 and 2 .

The $\lambda$ explains the gradual transference of particles from the raft to the pool of escapable particles and it is assumed that this process can follow a gamma distribution over the time (VIEIRA et al., 2008). The average $\lambda$ values did not differ $(\mathrm{P}<0.05)$. However, according to Figure 1, there was a small numerical difference in treated corn silage in relation to others. In this treatment, the transference rate was faster when compared with the values obtained for the other treatments.

Since the factors that influence the passage rate for the animal were not modified, the higher speed of transference can be attributed to the differences in the foods composition. Corn silage is a pure food of better quality and, therefore, presents a more degradable property when compared to other composed foods. Thus, it is suggested that corn silage is degraded in the raft, being that its particles are transferred quickly and almost all at once to the pool of eligible particles in the rumen exhaust.

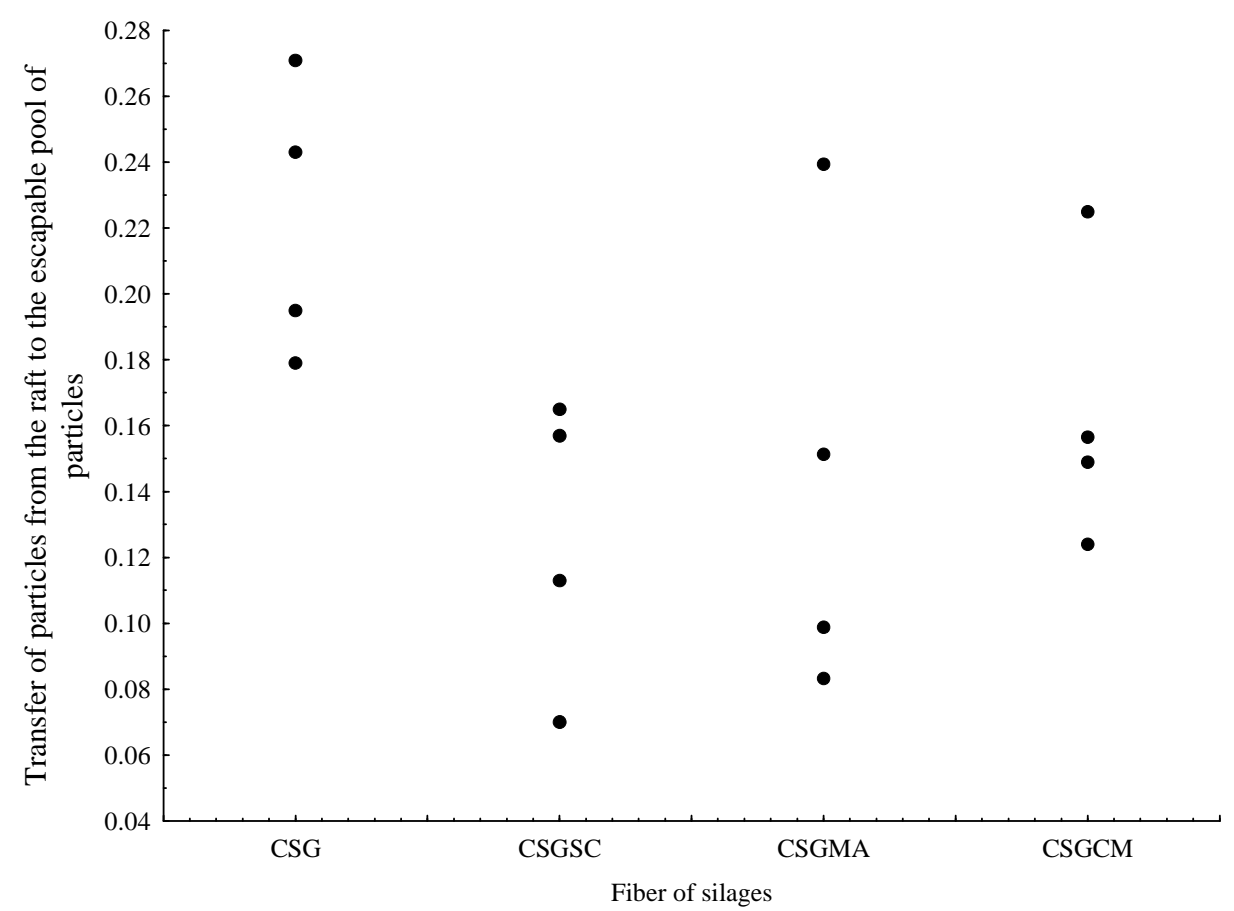

Figure 1. Particles transference from the raft to the pool of escapable particles 
Rev. Bras. Saúde Prod. Anim., Salvador, v.16, n.1, p.149-160jan./mar., 2015 http://www.rbspa.ufba.br

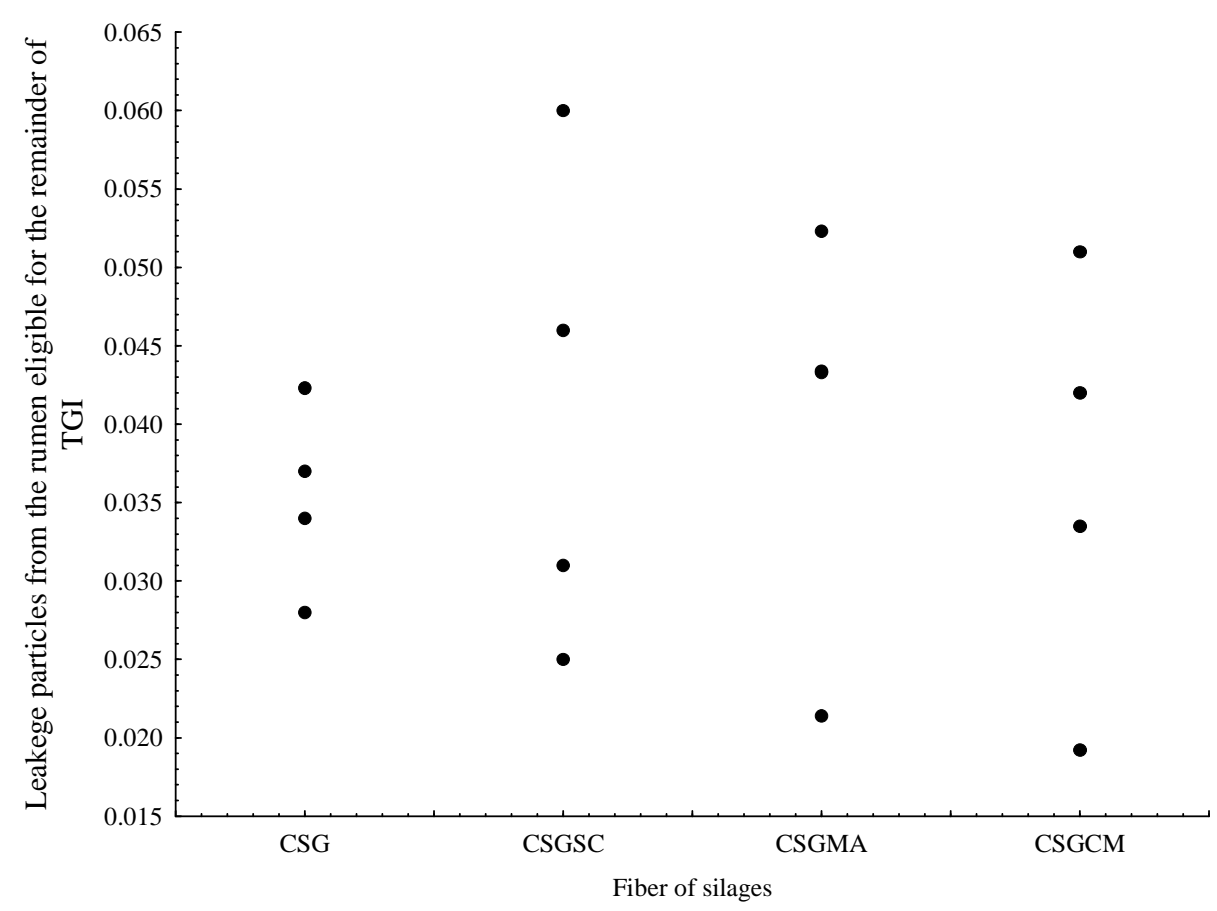

Figure 2. Escape from the rumen of particles eligible for the remainder of TGI

Indigestible particles contained in the escape pool will be eliminated after finding the escape rate, which is supposed to be exponentially distributed over time (VIEIRA et al., 2008).

The $\tau$ transit time is defined as the output time of the marker from the rumen until the first appearance in the feces, expressed in hours. The average values were not statistically different $(\mathrm{P}<0.05)$. However, there was less $\tau$ in the treatment, which used food as the CSGCM (Figure 3). After escaping of eligible particles from the rumen, there was no particle retention and digest flow was continuous, and the more fibrous the food is, the faster the flow occurs in the low gastrointestinal tract (GIT).

The average retention time in the raft (ATPR1) for the treatments were not statistically different $\quad(\mathrm{P}<0.05)$. However, the ATPR1 of the corn silage was numerically lower, when compared to the other treatments (Figure 4), especially in relation to treatments with corn, signal grass and calopogonio silage.

In the passage rate dynamics, the recently ingested particles fall directly into the raft, which is defined as the pool of larger fibrous particles, and float in the liquid phase of the rumen. The phenomena of preparation, colonization and digestion of the substrate occur in the raft, so it can be affirmed that the lower retention time in the raft for the corn silage occurs due to their qualitative characteristics, for it has a higher content of soluble carbohydrates compared to others.

Average retention time of particles in the rumen liquid phase (ATRLP2) for the treatments were not significantly different $(\mathrm{P}<0.05)$. It occurs due to the food characteristics, after escaping the raft and reaching the ATRLP2, which are very similar, considering that they have suffered most of the microbial degradation effects in the raft (Figure5). Finally, the average retention time in the rumen-reticulum (ATTRR), related 
Rev. Bras. Saúde Prod. Anim., Salvador, v.16, n.1, p.149-160jan./mar., 2015 http://www.rbspa.ufba.br ISSN 15199940

to the treatments in question, were not statistically different $(\mathrm{P}<0.05)$. It was observed small numerical differences among ATTRR in the different feed (Figure 6). The average values of
ATTRR obtained for corn silage were lower, when compared to other treatments, especially if compared with the treatment that employs CSGCM.

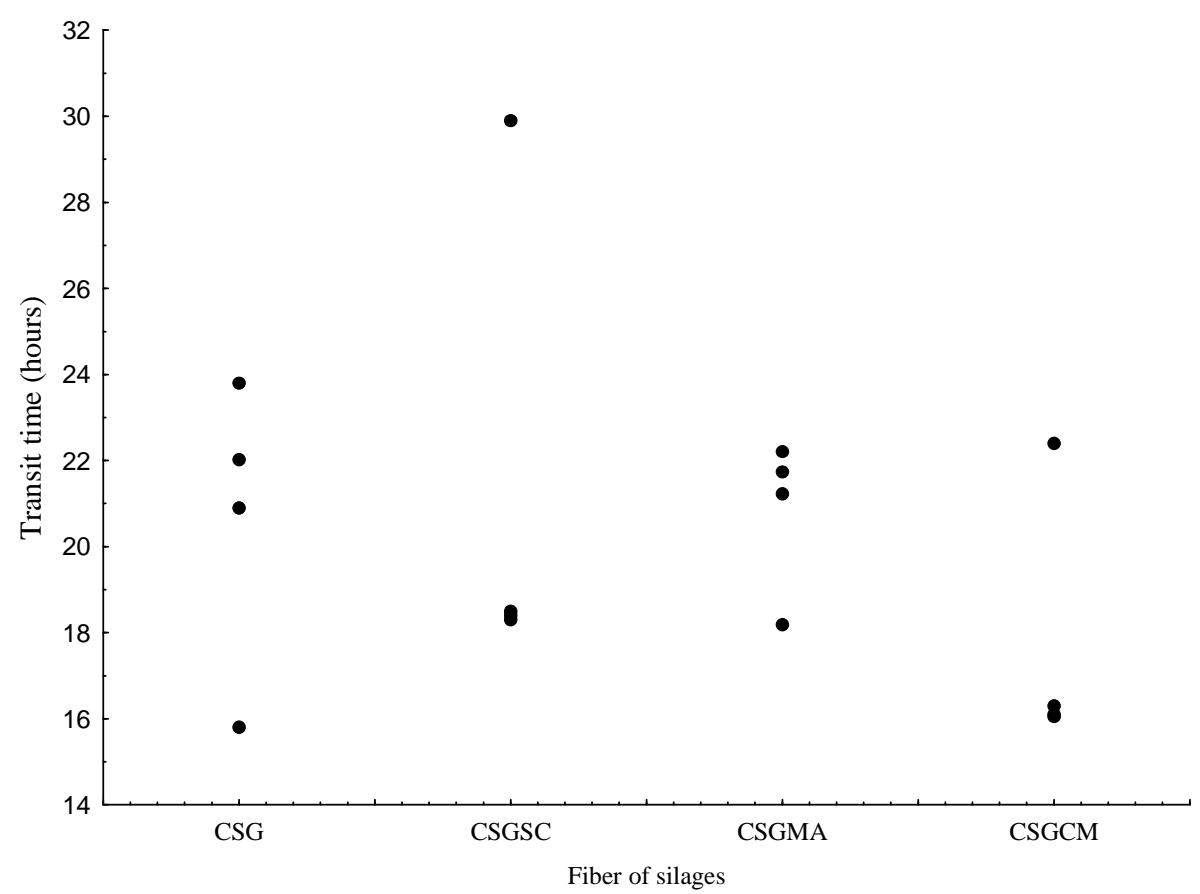

Figure 3. Transit time of the rumen output indicator and appearance in feces

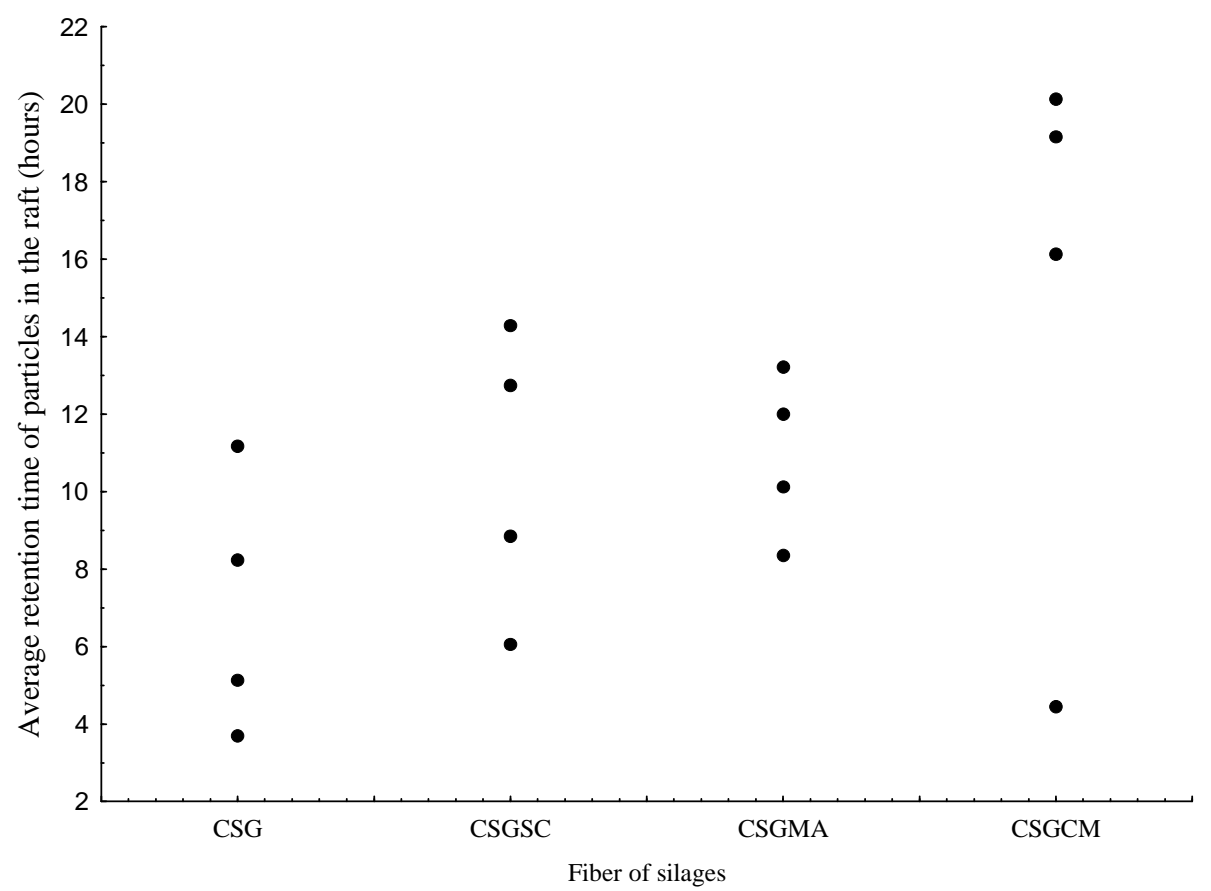

Figure 4. Average retention time of particles in the raft 
Rev. Bras. Saúde Prod. Anim., Salvador, v.16, n.1, p.149-160jan./mar., 2015 http://www.rbspa.ufba.br

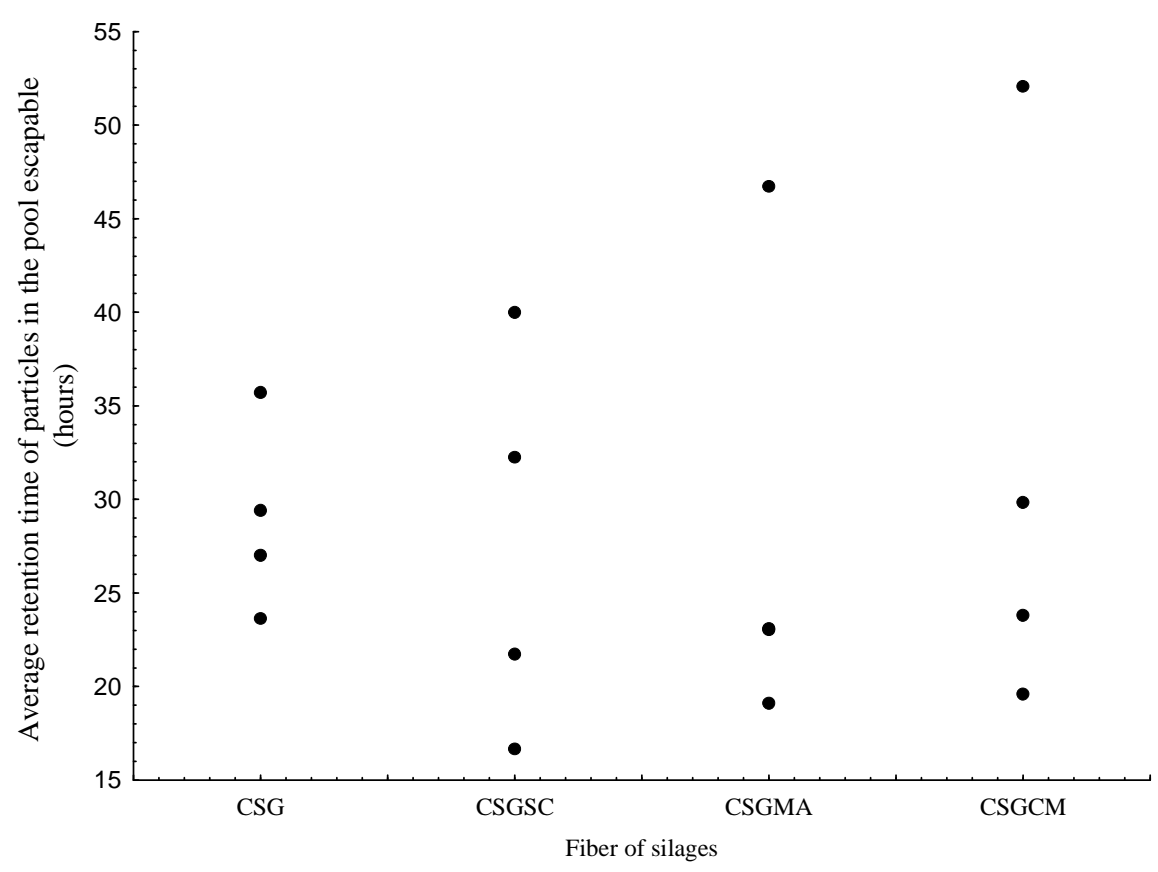

Figure 5: Retention time of particles in the escape pool

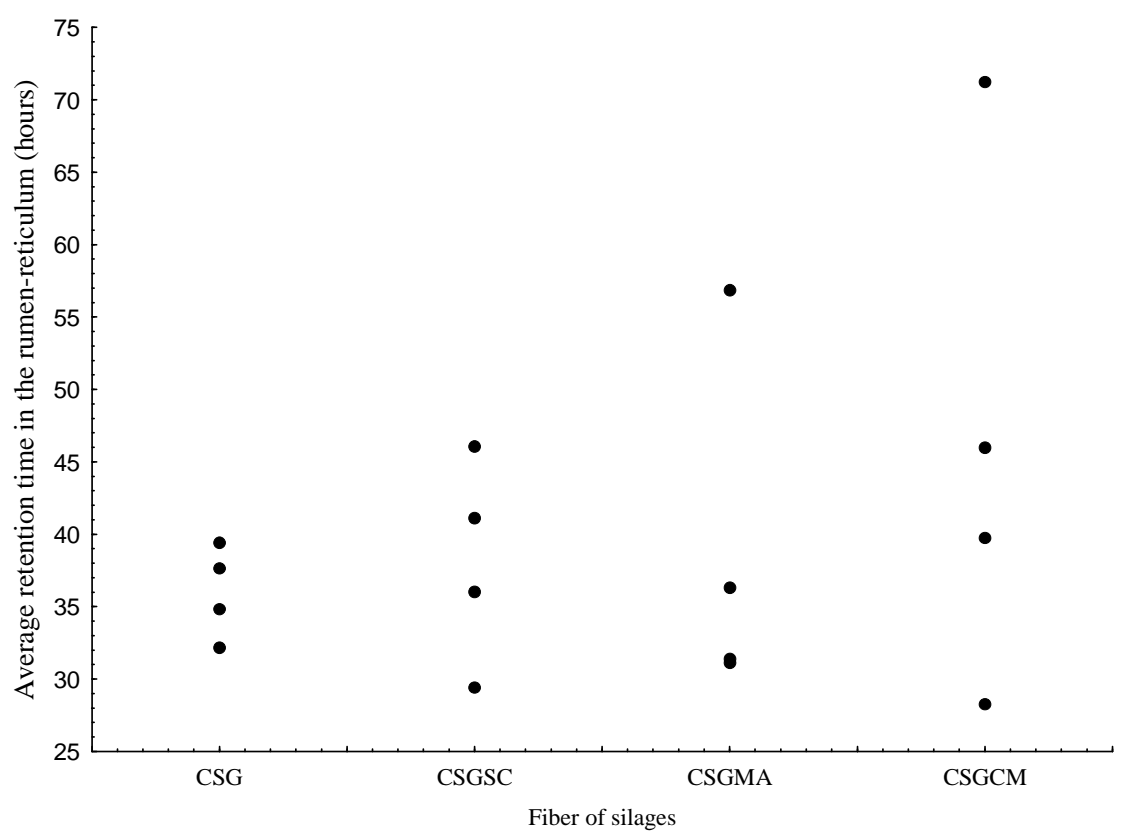

Figure 6. Average retention time in the rumen-reticulum

These results can be explained taking into account the food qualitative characteristics applied in different treatments, when the corn silage is degraded more rapidly in the rumenreticulum, due to its higher amount of soluble components. Thus, its respective retention time, in this fermentation compartment, is lower when compared to other treatments included in the present study.

The fibers of the silages evaluated in the present work had similar rates of $\lambda$, $\mathrm{k}$, TMR1, TMR2 and TMRR. Thus, the 
Rev. Bras. Saúde Prod. Anim., Salvador, v.16, n.1, p.149-160jan./mar., 2015 http://www.rbspa.ufba.br ISSN 15199940

selection of the consortium type to be employed effectively should be based on other factors, such as management and silage economy.

\section{REFERENCES}

AGRICULTURAL AND FOOD RESEARCH COUNCIL - AFRC. Energy and Protein Requirements of Ruminants. Walingford: CAB International, 1993, 159p.

\section{AGRICULTURAL AND FOOD} RESEARCH COUNCIL - AFRC. The nutrition of goats. Nutrition Abstracts and Reviews (Series B), v.67, n.11, p.765-830, 1997.

AKAIKE, H.A New Look at the Statistical Model Identification. IEEE Transactions on Automatic Control, v.19, p.716-723, 1974.

BARIONI, L.G.; VELOSO, R.F.; MARTHA JUNIOR, G.B. Modelos matemáticos aplicados a sistemas de produção animal em pastagens. In: SIMPÓSIO SOBRE MANEJO ESTRATÉGICO DA PASTAGEM, 2002, Viçosa. Anais... Viçosa, MG: Universidade Federal de Viçosa, 2002. p.235-278.

BEATON, A.E.; TUKEY, J.W. The fitting of power series, meaning polynomials, illustrated on bandspectroscopic data.

Technometrics, v.16, n.2, p.147-185, 1974.

BURNHAM, K.P.; ANDERSON, D.R. Multimodel Inference: Understanding AIC and BIC in Model Selection. Sociological Methods \& Research, v.33, p.261-304, 2004.
CHECKLAND, P. Systens thinking, systens practice. Chinchester: John Wiley \& Sons, 1989. 330p.

CRUZ, C.D.; REGAZZI, A.J. Modelos biométricos aplicados ao melhoramento genético. 2.ed. Viçosa, MG: Universidade Federal de Viçosa, 1997.390p

ELLIS, W.C.; MATIS, J.H. A role for rumen microbial protein synthesis in regulating ruminal turnover. Journal of Animal Science, v.79, p.104, 2001.

Suppl. 1.

FOX, D.G.; TEDESCHI, L.O.; TYLUTKI, T.P.; RUSSELL, J.B.; VAN AMBURGH, M.E.; CHASE, L.E.; PELL, A.N.; OVERTON, T.R. The Cornell Net Carbohydrate and Protein System model for evaluating herd nutrition and nutrient excretion. Animal Feed Science and Technology, v.112, p.29-78, 2004.

HUHTANEN, P.; KUKKONEN, U. Comparison of methods, markers, sampling sites and models for estimating digesta passage kinetics in cattle fed at two levels of intake. Animal Feed Science and Technology, v.52, p.141158, 1995.

LEONEL, F.P.; SOUSA, D.P.; BRUNETTO, G. Integração Lavoura Pecuária: produção e qualidade de forragens. In: LEONEL; F.P.; LIMA, I.B.; CARNEIRO, A.V. (Ed.) Produção sustentável de bovinos de leite. São João del Rei: Universidade Federal de São João del-Rei, 2009a. p.23-38.

LEONEL, F.P.; PEREIRA, J.C.; COSTA, M.G.; MARCO JÚNIOR, P. de; LARA, L.A.; Queiroz, A.C. de. Comportamento produtivo e características nutricionais do capim-braquiária cultivado em consórcio com milho. Revista Brasileira de Zootecnia, v.38, n.1, p.177-189, 2009b. 
Rev. Bras. Saúde Prod. Anim., Salvador, v.16, n.1, p.149-160jan./mar., 2015 http://www.rbspa.ufba.br ISSN 15199940

MATIS, J.H., WEHRLY, T.E., ELLIS, W.C. Some generalized stochastic compartment models for digesta flow. Biometrics, v.45, p.703-720. 1989.

NOCEK, J.E. In situ and other methods to estimate ruminal protein and energy digestibility. A review. Journal of Dairy Science, v.71, n.8, p.2051-2069, 1997.

NATIONAL RESEARCH COUNCIL NRC. Nutrients Requirements of Beef Cattle. 7th ed. Washington: National Academy Press, 1996. 242p.

NATIONAL RESEARCH COUNCIL NRC. Nutrient Requirements of Dairy Cattle. 7th ed. Washington:

QUIROZ, R.A., POND, K.R., TOLLEY, E.A., JOHNSON, W.L. Selection among nonlinear models for rate of passage studies in ruminants. Journal of Animal Science, v.66, p.2977-2986, 1988.

ROTHEMBERG, $\mathrm{J}$. The nature of modelling. In: WIDMAN, L.E.; LOPARO, K.O.; NIELSEN, N.R. (Eds.). Artificial intelligence, simulation and modeling. New York: Jonh Wiley and Sons, 1989. p.75-92.

SILVA, D.J.; QUEIROZ, A.C. Análise de Alimentos: métodos químicos e biológicos. 3.ed. Viçosa, MG:

Universidade Federal de Viçosa, 2002. $235 p$.

STATISTICA. Stat Soft is the creator of statistica, the most comprehensive suite of data mining and statistical analysis software. Address : <http://www.statsoft.com/\#>. Access: 1 Fev. 2011.
UDÉN, P.; COLUCCI, P.E.; VAN

SOEST, P.J. Investigation of chromium, cerium and cobalt as markers in digesta. Rate of passage studies. Journal Science Food Agricultural, v.31, n.7, p.625-632, 1980.

VIEIRA, R.A.M.; PEREIRA, J.C.; MALAFAIA, P.A.M. Simulação da dinâmica de nutrientes no trato gastrintestinal: aplicação e validação de um modelo matemático para bovinos a pasto. Revista Brasileira de Zootecnia, v.29, n.3, p.898-909, 2000.

VIEIRA, R.A.M.; TEDESCHI, L.O.; CANNAS, A.A. generalized compartmental model to estimate the fibre mass in the ruminoreticulum: 2 . Integrating digestion and passage.

Journal Theoretical Biology, v.255, p.357-368, 2008.

WILLIAMS, C.H.; DAVID, D.J.; IISMAA, D. The determination of chromic oxide in faeces samples by atomic absorption spectrophotometry. Journal Science Food Agricultural, v.59, n.2, p.381-385, 1962.

Data de recebimento: 21/08/2014

Data de aprovação: 15/03/2015 